\title{
SOVEREIGNTY AND JURISDICTION OVER ARCTIC WATERS
}

\section{ROBERT R. ROTH*}

The author reviews the development of the international legal regime with respect to Arctic waters, as it has evolved through five ages or eras of international attitudes towards the region. The author then assesses the current legal regime of Arctic waters, focusing on Canada's claims to sovereignty over these waters and the numerous and diverse legal theories which are being relied on to both support and rebut sovereignty claims. The author concludes with a critical examination of the adequacy of the legal regime in the Arctic.
L'auteur passe en revue l'évolution du régime de droit international relatif aux eaux de l'Arctique, d travers cinq rages» ou ères marquées par diverses attitudes envers la région. Il se penche ensuite sur le régime actuel, met l'accent sur les prétentions du Canada à la souveraineté et examine les théories nombreuses et diverses qui sont invoquées pour appuyer ou rejeter les revendications canadiennes. L'auteur termine par un examen critique établissant dans quelle mesure le régime de droit s'avère satisfaisant en ce qui touche l'Arctique.

\section{TABLE OF CONTENTS}

I. INTRODUCTION $\ldots \ldots \ldots \ldots \ldots \ldots \ldots \ldots \ldots \ldots \ldots \ldots$

II. THE NATURE OF ARCTIC WATERS $\ldots \ldots \ldots \ldots \ldots \ldots \ldots .846$

III. DEVELOPMENT OF A LEGAL REGIME

FOR ARCTIC WATERS $\ldots \ldots \ldots \ldots \ldots \ldots \ldots \ldots$

A. THE AGE OF INNOCENCE (1000

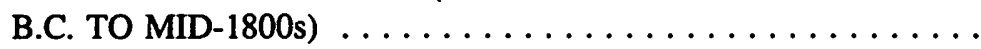

B. THE AGE OF DISCOVERY AND CONQUEST

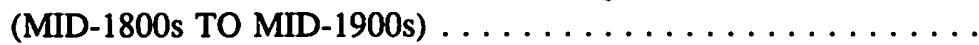

C. THE AGE OF UNDERSTANDING

AND MISUNDERSTANDING (1940s TO 1960s) ..........

D. THE AGE OF EXPLOITATION (1960s TO MID-1980s) $\ldots \ldots \ldots$

E. THE AGE OF UNCERTAINTY (MID-1980s TO ?) . . . . . . . 855

IV. THE CURRENT LEGAL REGIME OF ARCTIC WATERS . . . . . 856

A. CLAIMS TO INTERNAL WATERS $\ldots \ldots \ldots \ldots \ldots \ldots \ldots .657$

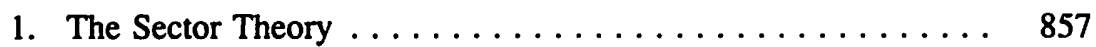

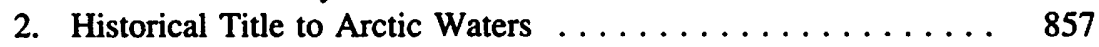

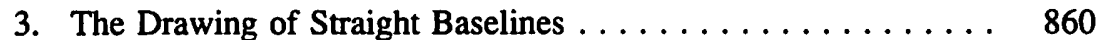

B. THE STATUS OF THE NORTHWEST PASSAGE $\ldots \ldots \ldots \ldots 864$

C. THE TERRITORIAL SEA \&

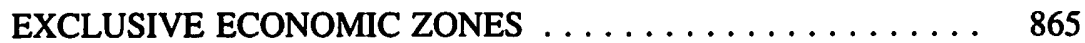

D. JURISDICTION UNDER THE ARCTIC

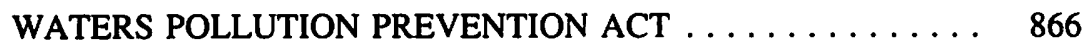

E. THE NATURE OF SEA ICE -- CLAIMS TO ICE AS LAND .... 867

F. AVOIDING STATUS -- LACK OF

SOVEREIGNTY IN THE ARCTIC $\ldots \ldots \ldots \ldots \ldots \ldots \ldots .868$

V. THE LEGAL FRAMEWORK OF ARCTIC

WATERS - A SYNTHESIS $\ldots \ldots \ldots \ldots \ldots \ldots \ldots \ldots$

Student-at-law, University of Alberta. This paper was a prize winning essay in the William Morrow Essay Contest for a Paper on Law or the Administration of Justice in the North. 


\section{INTRODUCTION}

Through a spirit of adventure, inquiry and conquest mankind has discovered, claimed, dominated and exploited virtually all regions of the earth. Sovereign and jurisdictional rights are generally recognized over all land areas of the earth, and the concept of gaining sovereignty over land that was once res nullius is all but obsolete. Thus, in recent history, the focus of mankind has shifted to the oceans and waters that cover a majority of the planet - these waters and the resources within and beneath them have become a new and increasingly important frontier for discovery, domination and exploitation. Of these waters, the most inaccessible and inhospitable are undoubtedly the waters of the Arctic Ocean and surrounding Arctic areas. The legal status of this "final frontier" remains unsettled to date, and the complexity and potential consequences of the resolution of this issue extend beyond what anyone could possibly have expected from a region once viewed as a forlorn wasteland.

It is ironic that this final frontier has become a leading edge for the development and application of the principles of international law with respect to the law of the sea. Thus far, the legal regime with respect to Arctic waters has been evolving as a struggle for and dispute over the rights to the use and control of these waters. The focus of international legal efforts and opinions in this area has thus been centred on questions of sovereignty and possible forms of jurisdiction over Arctic waters and the legal rights associated with these claims. There is serious doubt, however, as to whether a legal regime based on the rights associated with statehood and "ownership" of Arctic waters is adequate or appropriate to meet the political and regulatory needs of this region. The waters of the Arctic are an area of increasing strategic and economic importance, yet at the same time, this is an area with such a fragile ecosystem that a single failure of the legal regime could lead to disastrous consequences on a global scale. It is thus critical to assess and understand the current international legal environment regarding Arctic waters, to determine whether the resulting regime is adequate to meet the needs of the region and to consider whether other mechanisms or approaches available under international law would be more suitable - and perhaps even imperative - to cope with the unique and complex demands of this final frontier.

\section{THE NATURE OF ARCTIC WATERS}

To appreciate the international legal issues arising with respect to the waters of the Arctic, it is necessary to have a cursory understanding of the range and context of interests and considerations in this area. For the most part, these interests and the legal framework which is emerging to regulate them, have been based on the unique physical character of the region. Several basic features of the Arctic waters have made the region 
critical for strategic military purposes. ${ }^{1}$ The fact that the Arctic Ocean is a semi-enclosed sea separated from the waters of the south, its shallowness, its scoured bottom and its continuous ice cover make it a "strategic playground" for the nuclear missile-carrying submarines of the superpowers bordering the region. ${ }^{2}$ From an economic perspective, on the other hand, the shallow nature of the Arctic Ocean is indicative of large continental shelves bordering the Arctic coasts - some of which have proved to contain large oil and gas deposits.

Estimates of potentially recoverable reserves of crude oil range between 100 and 200 billion barrels compared to OPEC's proven reserves of crude oil approaching 440 billion barrels. Recoverable natural gas deposits may reach 2,000 trillion cubic feet...

Non-fuel mineral reserves adjacent to Arctic waters are also an important consideration, as extensive lead-zinc, iron, uranium and coal deposits in the region involve international trade and transportation concerns. ${ }^{4}$ These primary physical characteristics are essential considerations as the necessity of a concrete legal regime governing the use of Arctic waters has only become necessary in recent years as economic and military exploitation of the region's natural characteristics and resources have become feasible.

Working in tandem with the physical character of the Arctic Ocean and surrounding waters is the geopolitical structure of the region. From a general perspective, the region can be divided into two areas: "the Polar Basin, that area of high seas north of the territories of the circumpolar states; and that area encompassed by national jurisdiction, or what is known as the Arctic littoral."5 The Arctic littoral is comprised of the land and waters claimed by five nations: the United States, the Soviet Union, Canada, Denmark with Greenland and Norway with Svalbard. The adjacent jurisdictions of the two superpowers as well as the competing interests of major oil and gas producing nations have obvious ramifications for the political and legal environment of the region.

Ironically, this complex political and economic environment must exist within one of the most sensitive and essential ecosystems on the planet. The Arctic waters have a highly concentrated seasonal productivity and are the focus of extensive migrations of whales and seabirds seeking to take advantage of this phenomenon. As well, these waters are the subject of complex ocean currents, and combined with the effects of ice-cover and extreme cold, the ramifications of a serious oil spill could be catastrophic on a global scale. $^{6}$ The Arctic Ocean is a key factor in regulating the global climate, and both the potential for oil contamination and the fact that this region is a "sink" for long-range air

1. R.L. Friedheim, "The Regime of the Arctic - Distributional or Integrative Bargaining?" (1988) 19:6 Ocean Development and International Law 493 at 496.

2. G. Luton, "Strategic Issues in the Arctic Region", in Ocean Yearbook 6 (Chicago: The University of Chicago Press, 1986) 399 at 401.

3. D. VanderZwaag, J. Donihee \& M. Faegteborg, "Towards Regional Ocean Management in the Arctic: From Co-existence to Cooperation." (1988) 37 U.N.B.L.J. 1 at 12.

Ibid. at 14.

Luton, supra, note 2 at 400.

VanderZwaag, Donihee \& Faegteborg, supra, note 3 at 4; D.M. McRae \& D.J. Goundrey, "Environmental Jurisdiction in Arctic Waters: The Extent of Article 234" (1982) 16 U.B.C.L. Rev. 197 at 201. 
pollutants could drastically affect the earth's environment. ${ }^{7}$ To a great extent, the development of a legal regime in this region has been based on the necessity of protecting the area and minimizing the potential for serious environmental damage.

A final gloss must be added to this collage of interests, reflecting the social policy interests which become involved in the Arctic. The first of these concerns involves the Inuit - the traditional inhabitants of the region and long-time users of the Arctic waters and ice as an integral aspect of their lifestyle. ${ }^{8}$ Unfortunately, the current legal regime concerning Arctic waters has generally ignored this interest group, except to use them as support for legal arguments underlying national sovereignty claims (for example, the Canadian historic waters argument). The other social consideration which should be raised is the national sentiment or nationalism associated with the various Arctic littoral states. The most prominent example of this is the periodic surge in Canadian interest in the Arctic waters when Canadian sovereignty and national interests in the Arctic appear to be threatened. ${ }^{9}$ This consideration further complicates the development of a sound legal regime for the region and, even worse, often appears to draw attention away from the key conflicts and concerns regarding Arctic waters which should be the focus of legal efforts.

From this brief overview, the complicated and often contradictory nature and circumstances of the Arctic Ocean and surrounding waters should begin to emerge. The area represents both an irresistible opportunity for individual states to exploit vast natural resource wealth, while also representing a potential environmental time bomb should any of these individual efforts go awry. It is within this complex framework of global interests that the currently developing Arctic waters legal regime must be examined.

\section{DEVELOPMENT OF A LEGAL REGIME FOR ARCTIC WATERS}

As the various interests discussed above have waxed and waned in the eyes of the Arctic community, a system of laws has gradually emerged in an attempt to accommodate and manage them. At best, this legal framework can be said to have developed haphazardly, based for the most part on immediate reactions to critical Arctic incidents (such as the voyage of the S/T Manhattan through the Northwest Passage in 1969) ${ }^{10}$ at worst, it can be said to have developed negligently. To understand the framework that has been developing, and to assess whether it is in fact adequately managing the divergent interests in the Arctic, one must start by tracing where the various facets of international law (in some cases supplemented by domestic legislation) stem from. When the law of the Arctic is considered in this purposive fashion, several key weaknesses or flaws in

\footnotetext{
7. Ibid.

8. Ocean Management Working Group, Ocean Policy and Management in the Arctic, (Yellowknife: Canadian Arctic Resources Committee, 1984) at 27-28.

9. T.L. McDorman, "In the Wake of the 'Polar Sea': Canadian Jurisdiction and the Northwest Passage" (1986) 27 C. de D. 623 at 624-625.

10. C. Lamson \& D. VanderZwaag, "Arctic Waters: Needs and Options for Canadian-American Cooperation: (1987) 18 Ocean Development and International Law 49 at 50.
} 
current legal thought with respect to developing a workable legal regime for the Arctic emerge.

Developments regarding Arctic waters to date can be categorized into five phases, each corresponding to (1) a time period, (2) the use made of Arctic waters, (3) the predominant "world-view", especially with respect to the Arctic and (4) the legal claims and system being advocated. These phases, or "ages" as referred to below, are summarized in Table 1.

\section{TABLE I}

THE AGES OF THE ARCTIC WATERS

\begin{tabular}{|c|c|c|c|c|}
\hline Time Period & "Age" & Usage & World View & Legal View \\
\hline $\begin{array}{l}\text { time } \\
\text { immennorial }\end{array}$ & $\begin{array}{l}\text { the age of } \\
\text { innocence }\end{array}$ & $\begin{array}{l}\text { subsistence use } \\
\text { by Inuit }\end{array}$ & $\begin{array}{l}\text { local } \\
\text { community }\end{array}$ & $\begin{array}{l}\text { 1) local/tribe } \\
\text { 2) frozen } \\
\text { seas=land }\end{array}$ \\
\hline $\begin{array}{l}\text { late } 1800 \mathrm{~s} / \\
\text { early } 1900 \mathrm{~s}\end{array}$ & $\begin{array}{l}\text { the age of } \\
\text { discovery \& } \\
\text { conquest }\end{array}$ & exploration & territorialism & $\begin{array}{l}\text { 1) lands setiled } \\
\text { 2) sector theory } \\
\text { advanced }\end{array}$ \\
\hline \multicolumn{5}{|l|}{$\begin{array}{l}1940 \mathrm{~s} / \\
19503\end{array}$} \\
\hline & $\begin{array}{l}\text { the age of } \\
\text { understanding } \\
\text { \& mis under- } \\
\text { standing }\end{array}$ & $\begin{array}{l}\text { scientific and } \\
\text { military } \\
\text { exploration/use }\end{array}$ & $\begin{array}{l}\text { global } \\
\text { conflict/ } \\
\text { scientific } \\
\text { development }\end{array}$ & $\begin{array}{l}\text { 1) sector theory } \\
\text { diminishing } \\
\text { 2) informal } \\
\text { claim to } \\
\text { internal } \\
\text { waters } \\
\text { 3) Arctic Ocean } \\
\text { as high seas } \\
\text { 4) } 1958 \\
\text { Convention }\end{array}$ \\
\hline \multicolumn{5}{|l|}{$\begin{array}{l}\text { 1960s/1970s/ } \\
\text { mid-1980s }\end{array}$} \\
\hline & $\begin{array}{l}\text { the age of } \\
\text { exploitation }\end{array}$ & $\begin{array}{l}\text { economic, } \\
\text { scientific \& } \\
\text { military } \\
\text { exploration/use }\end{array}$ & $\begin{array}{l}\text { economic } \\
\text { development } \\
\text { versus } \\
\text { environmental } \\
\text { responsibility }\end{array}$ & $\begin{array}{l}\text { 1) } 12 \text { mile ter. } \\
\text { sea limit } \\
\text { 2) AWPPA } \\
\text { (1970) } \\
\text { 3) historic title } \\
\text { claims arise } \\
\text { 4) ICJ } \\
\text { jurisdiction } \\
\text { withdrawn } \\
\text { 5) exclusive } \\
\text { fishing zone } \\
\text { 6) UNCLOS III } \\
\text { (ending 1982) }\end{array}$ \\
\hline \multicolumn{5}{|l|}{ mid-1980s to? } \\
\hline & $\begin{array}{l}\text { the age of } \\
\text { uncertainty }\end{array}$ & $\begin{array}{l}\text { cconomic. } \\
\text { scientific \& } \\
\text { military } \\
\text { exploration/use }\end{array}$ & $\begin{array}{l}\text { nationalism } \\
\text { versus ins'l } \\
\text { cooperation }\end{array}$ & $\begin{array}{l}\text { 1) baselines } \\
\text { established a } \\
\text { disputed } \\
\text { 2) status of NW } \\
\text { passage } \\
\text { disputed } \\
\text { 3) ICJ } \\
\text { jurisdiction } \\
\text { re-accepted }\end{array}$ \\
\hline
\end{tabular}




\section{A. THE AGE OF INNOCENCE (1000 B.C. TO MID-1800s)}

Prior to European interest in and exploration of the Arctic waters, this region was the sole domain of the Inuit peoples. Archaeological evidence shows an extensive use of sea ice and the entire Arctic marine environment by these peoples since the advent of the Dorset culture (1000 B.C. to A.D. 800). " This use has been based on the treatment of sea ice as an extension of the land, which still holds some importance for modern legal reasoning, as will be discussed below. From a legal perspective, Inuit society was loosely structured and was "organized to exploit the resources available on the barrens and essential to sustain human life there."12 It can thus be concluded that the earliest legal regime of Arctic waters was based on a functional understanding of the Arctic environment (the nature of sea ice, etc.) and the basic societal needs of the Arctic peoples.

\section{B. THE AGE OF DISCOVERY AND CONQUEST (MID-1800s TO MID-1900s)}

The aboriginal legal regime of the Inuit remained unchallenged and unchanged until the early 1800 s, as the distribution of Arctic lands became an issue for the circumpolar nations. For the most part, claims during the 1800 s, and even the early 1900 s, concentrated primarily on delimiting land possessions. This is evidenced by several treaties of this time period including the 1825 Treaty between Great Britain and Russia ${ }^{13}$ and the 1867 Treaty between the United States and Russia. ${ }^{14}$ The generally accepted view of these treaties is set out by Pharand: ${ }^{15}$

The meridians were used as convenient geographical devices with which Russia and Great Britain delimited their possessions along the coast and the islands in 1825, and within which the dominion or sovereignty over the territory was ceded by Russia to the United States in 1867. In both instances, the subject matter was land only, and not land and sea, except for inland waters and the territorial sea.

This predominant preoccupation with land areas was still the case when Senator Pascal Poirier invoked the sector theory in 1907 as a basis for claiming sovereignty over all land and islands north of Canada, and when Captain J.E. Bernier took formal possession of the whole Arctic Archipelago for the Dominion of Canada on July 1, 1909..$^{16}$ A similar decree claiming lands and islands located in the Arctic Ocean north of the U.S.S.R. was

Ocean Policy and Management in the Arctic, supra, note 8 at 98. Hamlet of Baker Lake v. Minister of Indian Affairs and Northern Development (1980), 107 D.L.R. (3d) 544 as discussed in Ocean Policy and Management in the Arctic, supra, note 8 at 98. sur la cote Nord-Ouest de l'Amerique... 16/28 Janvier 1825, Recueil de Martens, Nouvelle serie, Vol. II at 427-8 as cited in D. Pharand, Canada's Arctic Waters in International Law (Cambridge: Cambridge University Press, 1988) Appendix A at 258. Vol. 134, at 332 as cited in Canada's Arctic Waters in International Law, supra, note 13, Appendix B at 265. 
adopted by the Presidium of the Central Committee in 1926. ${ }^{17}$ These land-based views lasted until the 1920s when the last challenges to Canada's title over its Arctic islands were settled (Denmark with respect to Ellesmere Island in 1920 and Norway with respect to the Sverdrup Islands in $1928-30) .{ }^{18}$

Thus, a legal regime based on absolute sovereignty had developed with respect to Arctic lands by the beginning of the 1930s. For the most part, however, Arctic waters had been ignored, except as a vehicle or route to the discovery of northern lands. Even though not explicitly considered, though, the law pertaining to Arctic waters had taken a dramatic shift. With all land areas spoken for, questions regarding jurisdiction and sovereignty over the adjacent waters began developing as a system of rights attached to the control and ownership of land -- a system very different from the rudimentary social systems of the Inuit. This can be seen in concepts such as the territorial sea, introduced to the Arctic from general maritime law coincident with the acquisition of title to Arctic lands.

\section{THE AGE OF UNDERSTANDING AND MISUNDERSTANDING (1940s TO 1960s)}

With questions pertaining to Arctic lands resolved, attention began to shift to the next frontier -- the waters of the Arctic per se. This increased attention also reflects technological improvements making navigation of Arctic waters easier, as well as an increase in actual and potential uses for the Arctic region. (Such as the U.S. requests in 1946 to allow the U.S. Navy to carry out training exercises in the Canadian Arctic and to permit the installation of an Arctic weather station.) ${ }^{19}$ World War II and the subsequent split in U.S.-Soviet relations significantly heightened the strategic military importance of the Arctic waters, and at the same time reduced the willingness of states to cooperate in this arena. During the same time period, and perhaps spurred by political developments and military requirements, scientific interest in the Arctic heightened. ${ }^{20}$ By the end of the 1950s, scientific exploration also included the economic potential of the Arctic, and between 1958 and 1962 the Canadian government began actively encouraging the oil industry to consider the petroleum production potential of the Arctic regions. ${ }^{21}$ Thus, during this age of scientific understanding and global misunderstanding, existing Arctic interests expanded considerably and critical economic interests began to move to the fore.

Unfortunately, Arctic legal developments lagged behind the developments in other areas, and little progress was made in terms of establishing a workable legal regime. The

17.

L. Kutner, "The Arctic Ocean: A Contest of Sovereignty" (1983) 8:5 The Common Law Lawyer 1 at 5 .

18. D. Pharand, "Canada's Arctic Jurisdiction in International Law" (1983) 7 Dalhousie L.J. 315 at 315 316. Canada's Arctic Waters in International Law, supra, note 13 at 53.

20. For example, Ice Island T-3 has been continuously occupied by scientists from the United States since 1952. See Kutner, supra, note 17 at 8.

21. I.T. Gault, The International Legal Context of Petroleum Operations in Canadian Arctic Waters (Calgary: The Canadian Institute of Resources Law, 1982) at 8. 
sector theory continued to be bantered about, primarily by Canadian officials, although with little effect. To avoid tracing and restating the confusing, contradictory and somewhat embarrassing use of the sector theory by Canada during the 1940s, '50s and ' 60 s, suffice it to say that the theory did little more than confuse both the domestic and international legal communities as to Canada's position with respect to Arctic waters and that it has now been unequivocally rejected.22

Beyond the sector theory, however, several other approaches were attempted with respect to advancing legal claims over Arctic waters. During the 1950s and early 1960 s, both Canada and the Soviet Union advanced claims that their northern waters were 'territorial ' or 'internal' (these concepts are not the same; however, it is unclear what was meant by the actual claims advanced). In 1957, after answering questions regarding three U.S. ships that had crossed the Northwest Passage, Prime Minister St. Laurent stated in the House of Commons that these waters were considered Canadian territorial waters by the government. ${ }^{23}$ In assessing this statement, Donat Pharand has concluded that "[i]t is very obvious from the context that the term 'territorial waters' was being used as synonymous with the modern expression 'internal waters '."24 Several years later, in 1960, the U.S.S.R. adopted the Statute on the Protection of the State Border of the U.S.S.R. providing that "internal sea waters of the U.S.S.R. shall include ... waters of bays, inlets, coves, and estuaries, seas and straits, historically belonging to the U.S.S.R." ${ }^{25}$ Although the Soviet Union has restricted the access of American ships to its waters, the restrictions have fallen somewhat short of a perfect claim to internal waters. Soviet jurists generally agree, though, that these waters are internal to the U.S.S.R. on the basis of historic usage. ${ }^{26}$ The Canadian claim, on the other hand, is more uncertain, and appears to be a 'one time' statement, not substantiated until more specific claims to internal waters were advanced in the 1970s.

An opposite approach was taken by the United States (and less explicitly by the remaining Arctic nations) by refusing to make claims to the Arctic waters. "The U.S. believed no state could or should claim water or ice as territory. It has preferred instead to exploit the Arctic region in its entirety, regarding it as res communes. ${ }^{27}$ It is interesting to note that this approach has generally been accepted with respect to the waters of the Arctic Ocean itself, which is now regarded as high seas.

22. For a full discussion of the Canadian use of the sector theory which inevitably leads to this conclusion, see either Canada's Arctic Waters in International Law, supra, note 13 at 46-49, or Kutner, supra, note 17 at 6-7. The sector theory was effectively dismissed in 1969 by Prime Minister Trudeau, but did not ultimately disappear conclusively until 1985 , when Canada passed legislation drawing straight baselines around the Arctic Archipelago.

D. Pharand, Note, "Canada's Sovereignty over the Newly Enclosed Arctic Waters," in The Canadian Yearbook of International Law 1987 (Vancouver: UBC Press, 1988) 325 at 325.

Canada's Arctic Waters in International Law, supra note 13 at 121.

Soviet Statues and Decisions, Vol. III, No. 4 at 9 (Summer 1967) as in Canada's Arctic Waters in International Law, supra, note 13 at 108.

Canada's Arctic Waters in International Law, supra, note 13 at 109.

Kutner, supra, note 17 at 6. 
Overall, although several important advances were made to develop a legal regime for the Arctic waters, for the most part the law pertaining to the region remained incoherent, unclear and uncertain. In fact, it would not be unreasonable to say there was still basically no law pertaining to Arctic waters during this period. ${ }^{28}$ Even the customary international law that had developed or was developing with respect to marine areas in general during the 1940s and 1950s (for example, historic waters or the drawing of straight baselines) was not being extrapolated and applied to the waters of the Arctic. From Canada's perspective, the only law applicable to the area was the implicit definition of a three mile territorial sea in the Criminal Code, supplemented by a definition of "territorial waters" in the Coastal Fisheries Protection Act. ${ }^{29}$ This virtually complete lack of some form of even rudimentary legal framework for the Arctic waters is undoubtedly due primarily to the lack of specific claims or definitive challenges to sovereignty over these waters. Of the five Arctic states, the U.S.S.R. appears to have had the most functional success during this era, primarily due to its enforcement of its international policies, apart from any legal framework in the region.

By the end of this period, however, the importance of the Arctic waters was unmistakable. The law of the sea had taken on increasing importance in general during this time, as is evidenced by the 1958 Geneva Convention on the Territorial Sea. ${ }^{30}$ Furthermore, interests in the Arctic were beginning to conflict as the dangers of military and economic use of the Arctic became evident. The need for a workable legal regime was thus becoming unavoidable -- all that was required was a catalyst to make this conclusion a necessity.

\section{THE AGE OF EXPLOITATION (1960s TO MID-1980s)}

The necessary catalyst referred to above came in the form of the Arctic oil boom. Offshore exploration in the Canadian Arctic began in 1961, with the first well discovered in 1974. ${ }^{31}$ Onshore exploration, however, had been successful long before this. These discoveries and the need to transport petroleum resources spurred environmental concerns regarding Arctic waters - a key interest in the region during this time period. If any single event can be pinpointed as the beginning of this era, it is the 1969 Arctic voyage by the S/T Manhattan through the Northwest Passage. ${ }^{32}$ In fact, from the perspective of many authors, this appears to have heralded the advent of the modern law of Arctic waters.

As a result of developments in the Arctic, and in particular the problems posed by the Manhattan, the Canadian government took several steps to assert its jurisdiction over

For example, in Canada's case in particular, no formal sovereignty claim had been established to the waters of the Arctic archipelago and no domestic legislation defined their legal status or the status of the Northwest Passage. See M. Killas, "The Legality of Canada's Claims to the Waters of its Arctic Archipelago (1987) 19 Ottawa L. Rev. 95 at 95-96.

32. See Killas, supra, note 28 at $95-96$. 
Arctic waters. First, a 12-mile territorial limit was declared along all Canadian coastlines (including the Arctic) in early 1970 , extending the previous three mile limit. ${ }^{33}$ Second, the Arctic Waters Pollution Prevention Act was enacted in 1970 creating a 100-mile pollution prevention zone around Canada's Arctic coasts. ${ }^{34}$ The Preamble of the Act explicitly indicates that the $A c t$ was adopted to protect the Inuit and the Arctic marine environment. ${ }^{35}$ At the same time, Canada deposited a reservation to its acceptance of the compulsory jurisdiction of the International Court of Justice with respect to conservation, management or exploitation of living resources of the sea and in respect of the prevention or control of pollution in marine environments. ${ }^{36}$ This move was necessary due to the view of several countries that the Arctic Waters Pollution Prevention Act was in contravention of existing international law. As well, and presumably also connected to the potential international illegality of the Act,

[d]uring the 1970s, Canada expended considerable energy in having the international community recognize the legitimacy of [this] ... legislation. The Canadian Government has claimed success in this quest with the inclusion in the 1982 United Nations Convention on the Law of the Sea of Article $234.37 p^{38}$

Finally, on March 1, 1977, Canada established an Arctic fishing zone, extending its jurisdiction to 200 nautical miles from the coasts (this zone is related to the exclusive economic zone eventually provided for under the 1982 LOS Convention). ${ }^{39}$

In addition to these concrete governmental actions, beginning in 1969 and 1970, numerous government statements indicated that Canada views the waters of its Arctic Archipelago as internal waters on an historic basis. These claims began with considerable uncertainty starting with Prime Minister Trudeau's ambiguous claim to internal waters in 1969 and subsequent statements of the Bureau of Legal Affairs in $1973 .^{40}$ Exactly when Canada's position became clear is a matter of some dispute. Several authors feel Canada's position that the waters of the Arctic Archipelago are internal became unequivocal when this view was explicitly stated in 1975 by Allan MacEachern, Secretary of State for Foreign Affairs. ${ }^{41}$ On the other hand, at least one author believes Canada's views with respect to Arctic sovereignty were not clearly articulated until Joe Clark's statements surrounding the establishment of baselines around the Arctic Archipelago in $1985 .^{42}$ Canada's claim (until the establishment of baselines in 1985-86) was based entirely on the view that the waters of the Canadian Arctic Archipelago are internal on an historic basis (first enunciated in the Legal Bureau statement in 1973). ${ }^{43}$ The

Ibid. at 96.

Arctic Waters Pollution Prevention Act, R.S.C. 1985, c. A-12.

Canada's Arctic Waters in International Law, supra, note 13 at 169.

McDorman, supra, note 9 at 626.627.

Ibid. at 627.

Convention on the Law of the Sea, U.N. Doc. A/Conf. 62/122 f(1982), also at 21 I.L.M. 1261

(hereinafter 1982 LOS Convention.

Canada's Arctic Jurisdiction in International Law, supra, note 18 at 326.

See Killas, supra, note 28 at 100 and McKinnon, supra, note 29 at 796.

This view is discussed and supported by McKinnon, supra, note 29 at 795-96, and Pharand, "Canada's Arctic Jurisdiction in Intemational Law" supra, note 18 at 329.

Killas, supra, note 28 at 100-101.

Canada's Arctic Jurisdiction in International Law, supra, note 18 at 329. 
acceptability of this view from an international perspective is highly questionable, though, as will be discussed below.

Thus, during this period, Canada was forced to clarify its position with respect to its Arctic waters in an attempt to establish a balance between the various uses of the Arctic waters that had developed to this point and the environmental needs of the region that became evident as marine petroleum development and transportation became significant possibilities in the Arctic. The practices and policies of the other Arctic states regarding Arctic waters during this period, however, did not change to any significant extent, with the United States (and presumably Norway and Denmark) continuing to advocate freedom of the seas and the U.S.S.R. relying to some extent on the principles of historic waters. ${ }^{44}$ The legal regime of the Arctic waters thus expanded significantly based solely on several unilateral actions of the Canadian government asserting jurisdiction over the waters within and surrounding the Arctic Archipelago. This expansion involved both the application of existing principles of customary and treaty law (the declaration of a 12-mile territorial sea and establishment of a 200-mile fishing zone) and the creation of new customary law (by breaching existing customary law through the passage of the Arctic Waters Pollution Prevention Act and eventually gaining the approval of the international community for this act). Perhaps even more significantly, however, the first clear assertions of complete sovereignty over these waters were made by the Canadian government (based on the customary international law principle of historical usage).

It should be remembered that Canada's claims to additional jurisdiction and sovereignty in the Arctic were supposedly based on a concern for the fragile social and environmental character of the Arctic marine regions (although some authors ascribed these actions to blatant nationalism from the outset). ${ }^{45}$ As Canada advanced a position closer to complete sovereignty over the waters of its archipelago, the question thus arose whether Canada's claims of jurisdiction and sovereignty adequately protected the needs of the Arctic environment or whether, in fact, they had gone beyond this point and become a claim to sovereignty for the sake of nationalistic interests as some writers had claimed. This issue became more pronounced as Canada faced increasing external challenges and internal pressures and took further steps to declare complete sovereignty over its Arctic waters.

\section{E. THE AGE OF UNCERTAINTY (MID-1980s TO ?)}

Canada took the ultimate step in declaring sovereignty over its waters in 1985, after national interests had once again been aroused by the voyage of the U.S. Coast Guard icebreaker Polar Sea through the Northwest Passage, by drawing straight baselines around the Arctic Archipelago declaring the waters to be internal waters and requiring other states to request Canada's permission to enter them. ${ }^{46}$ At the same time, Canada withdrew its 1970 reservation to the International Court of Justice's jurisdiction to emphasize that it 
stood ready to have its claim adjudicated ${ }^{47}$ Through these actions, Canada has ultimately attempted to unilaterally create a legal regime for Arctic waters based on a notion of complete sovereignty. To a certain extent, Canada's actions have been supported by the adoption of a decree in the U.S.S.R. enclosing three Soviet Arctic archipelagos with straight baselines. ${ }^{48}$ The Canadian view, however, has been challenged by other nations, most notably the United States, and the overall international legal position in the Arctic is as unclear and uncertain as ever. So, although a complete arsenal of customary international legal principles and treaty provisions (from the 1958 Convention and the 1982 LOS Convention) have been amassed by both sides, their meanings are unclear and their application to the waters of the Arctic is uncertain. It is thus debatable whether there is much more of a legal regime governing Arctic waters today than there ever has been in the past.

The overall uncertainty inherent in this region is further emphasized by a recent toning down of rhetoric between Canada and the U.S., a 1988 agreement between Canada and the U.S. regarding use of Canadian waters ${ }^{49}$ and overtures on the part of the U.S.S.R. to establish cooperative efforts in the Arctic. ${ }^{50}$ As opposed to Canada's original claims of complete sovereignty, these occurrences would all indicate a potential movement to cooperation outside the rigid boundaries of sovereignty. Thus, the question that must be answered during this 'age of uncertainty' is whether the next age of Arctic waters will be an age of division based on individual states claiming sovereignty and establishing individual jurisdictional regimes or whether it will be an age of international cooperation focusing on the interboundary functional problems and issues arising regarding the waters of the Arctic.

\section{THE CURRENT LEGAL REGIME OF ARCTIC WATERS}

To even approach an answer to this penultimate question, the current legal arguments regarding the waters of the Arctic must be understood and assessed. The areas which must be considered include (1) claims to Arctic waters as internal waters, (2) the status of the Northwest Passage, (3) the effects of territorial seas and exclusive economic zones, (4) jurisdiction over Arctic waters through the Arctic Waters Pollution Prevention Act, (5) potential claims to the Arctic waters as "land" (the nature of sea ice) and (6) alternatives and claims which avoid determining the status of Arctic waters. Although the legal arguments pertaining to each of these issues have been carefully explored and outlined by numerous authorities, their ultimate result is still a matter for debate. What is required is an overall conclusion as to where current developments in the international law of the Arctic are heading and whether this direction is appropriate given the unique needs of this region.

\section{A. CLAIMS TO INTERNAL WATERS}

47.

48.

49.

so.

Ibid.

Ibid. at 331-332.

Note, "Icebreaker Voyages in Arctic - U.S. Canadian Agreement" (1988) 82 American Joumal of International Law 340-341.

VanderZwaag, Donihee \& Faegteborg, supra, note 3 at 29. 
The claims by Canada and the U.S.S.R. to certain of the Arctic waters as internal waters are the most extensive claims that can be made -- amounting, in essence, to a claim of complete national sovereignty and jurisdiction over these waters. Over time, these claims have been founded on three possible bases: the sector theory, historical title and the drawing of straight baselines.

\section{The Sector Theory}

The sector theory is a claim based on the complete division of the Arctic Ocean and surrounding waters amongst the Arctic states along lines of longitude approximating the existing coastlines of these states. ${ }^{51}$ Originally developed as a means to claim land, the sector theory was toyed with by both Canada and the U.S.S.R. as a means for claiming sovereignty over Arctic waters to the North Pole during the first half of the twentieth century. ${ }^{52}$ This theory, though, was rejected either expressly or implicitly by the other Arctic nations, never developed into a principle of customary international law and has now been wholly abandoned. ${ }^{53}$

\section{Historical Title to Arctic Waters}

The claim to sovereignty over waters on the basis of historical title, on the other hand, is clearly an accepted part of customary international law and has been relied on by both Canada and the U.S.S.R. in the Arctic. Although originally a doctrine developed to allow states to claim bays which could not be claimed as internal waters using ordinary closing rules, the principle of historical waters has generally been accepted as applying to straits and other bodies of water as well. There is some debate as to whether the determination that waters are historic results in their being internal waters or whether they simply become territorial waters. Although a U.N. Secretariat study in 1962 concluded that the legal status of internal waters would depend on the type of sovereignty exercised by the state claiming historical waters, the most forceful view is that historic title results in the status of internal waters regardless of the type of waters being considered and the actions of the state involved. ${ }^{54}$ This conclusion would mean that a declaration that certain waters were historic would give the state concerned complete sovereignty over them.

The 1962 study referred to above also formulated the basic factors which have now been accepted as the basis for a claim to historic waters, namely::5s

\footnotetext{
51. McKinnon, supra, note 29 at 811-812.

52. See the discussion in Part III, Sections B and C, supra, of details.

53. This is the conclusion of virtually all writers. See for example McKinnon, supra, note 29 at 813 and Pharand, "Canada's Arctic Jurisdiction in International Law", supra, note 18 at 323-324.

54. Canada's Arctic Waters in International Law, supra, note 13 at 93 where Pharand refers to Juridical Regime of Historic Waters, including Historic Bays, A/CONF, 4/143 (March 1962) but concludes that customary international law as applied in the Anglo-Norwegian Fisheries Case [1951] I.C.J. Rep. at 130 leaves no doubt that historic waters are internal waters. 
(1) the exercise of authority over the area by the state claiming the historic right;

(2) the continuity of this exercise of authority;

(3) the attitude of foreign states.

The claims of both Canada and the U.S.S.R. must be considered in light of these factors. Unfortunately, the concept of historic waters has never been directly considered by the International Court of Justice, and thus each of these criteria is subject to interpretation. Generally, little is known about the Soviet position in this regard. Although legislation exists which provides for historic seas and straits, no clear claims exist on the part of the Soviet government; however, Soviet jurists are unanimous in claiming several of the Siberian seas and straits as internal waters on an historical basis. ${ }^{56}$ Given the limited evidence, it is impossible to come to any conclusion as to the full extent and validity of the Soviet claims.

Far more evidence exists regarding the Canadian position:

(1) Exercise of authority over the area by the state: To establish a valid claim to historic (or internal) waters, the state must claim the right to absolutely prohibit navigation by all foreign vessels. ${ }^{57}$ Any claim less than this could be construed as merely asserting jurisdiction under a territorial waters regime. As well, this claim must extend beyond the mere intent of the state, but must encompass any acts or deeds necessary to maintain control and sovereignty ${ }^{58}$ Obviously, if sovereignty was not being challenged, these acts would be very minimal. ${ }^{59}$ The first question to be asked is thus whether sufficient declarations and acts of sovereignty were completed by Canada to justify their northern waters being classified as historical.

Canada has clearly claimed the waters of its Arctic Archipelago as internal since 1975. ${ }^{60}$ Prior to this, Canada's intent was unclear and undoubtedly fell short of a complete claim to sovereignty over the region. In terms of actions, Canada has had legislation in place to ensure complete sovereignty over its Arctic waters since the establishment of straight baselines around the Archipelago in 1986. Even this, however, may be insufficient to support a claim to total sovereignty. Prior to this, legislation only existed regarding the territorial seas, fishing zones and pollution prevention measures. These statutes clearly fall short of the claim to absolute sovereignty required for historic waters, and in the case of the Arctic Waters Pollution Prevention Act a claim to sovereignty was explicitly ruled out by the Secretary of State

S.M. Olenicoff, Territorial Waters in the Arctic: The Soviet Position, (Santa Monica: Rand, 1972) at 24-27; and Canada's Arctic Waters in International Law, supra, note 13 at 110.

57. McKinnon, supra, note 29 at 794-795.

38. Canada's Arctic Waters in International Law, supra, note 13 at 98.

59. This view would be analogous to the limited acts of sovereignty found to be necessary in the Legal Status of Eastern Greenland Case (1933) P.C.I.J. Ser. A/B, No. 53 due to the nature of the land being claimed.

6.

See supra, note 41 . This was the first clear statement of intent made by the government per se; the Legal Bureau of Extemal Affairs made a statement prior to this in 1973 clearly viewing the waters of the Arctic Archipelago as intemal. 
for External Affairs. ${ }^{61}$ As well, Canada has not had the opportunity to directly enforce its sovereignty claim by refusing entry to a foreign ship or by adjudicating on the question of sovereignty in a domestic court. ${ }^{62}$ It may thus be concluded that Canada has only had a clear intent to exercise complete sovereignty over its Arctic waters since 1973-75, and has only instituted effective legislation in this regard since 1986. At this point in time, though, Canada has arguably satisfied the requirements of the first part of the historic waters test -- an intention and corresponding actions to exert sovereignty over the region have co-existed since 1986.

(2) The continuous exercise of authority: The second requirement for historic waters is a well-established or continuous and long standing usage of the waters in question. ${ }^{63}$ Here, it is submitted, Canada undoubtedly falls afoul of the basic requirements. Both a clear intent and (arguably) sufficient acts have only existed for fourteen years and three years respectively. As mentioned previously, declarations and actions prior to this did not amount to proof with respect to establishing complete sovereignty. Although no definitive time limit for claims to historic waters has been established, and Canada can thus argue that its acts are sufficient, the reluctance to declare the Arctic waters north of Canada internal and the even greater reluctance to take legislative or administrative actions in this regard will most likely defeat a Canadian claim.

(3) The attitude of foreign states: The final requirement for a claim to historic waters has generally been recognized as the acquiescence of foreign states. ${ }^{64}$ Although few states have protested or challenged Canada's claims to sovereignty, the most interested foreign state, the Unites States, has voiced consistent opposition to Canadian moves toward greater sovereignty and has, in effect, challenged Canadian sovereignty over the Northwest Passage through its actions. ${ }^{65}$ Based on existing evidence, though, there is room to move on both sides of this position -opposition to Canada's claims have only come from one state, and for the most part these opposing claims have only been verbal; at the same time, though, American opposition has been consistent and strongly voiced. Combined with the effects of Canada's potentially inadequate acts of authority and the short period of time during which sufficient authority would have been exercised, the opposition of the United States would undoubtedly destroy Canada's claim to the waters of the Arctic Archipelago on an historic basis.

Canada, House of Commons, Debates at 5951 (16 April 1970).

McKinnon, supra, note 29 at 798-799.

Canada's Arctic Waters in International Law, supra, note 13 at 98.

McKinnon, supra, note 29 at 799.

Ibid. Although Canada had given its permission for all uses of it archipelagic waters, it can hardly be doubted that the United States would have acted as it did without Canada's consent. Consent was, in essence, simply a protective move on the part of the Canadian government. 


\section{The Drawing of Straight Baselines}

The decision of the Canadian government to draw straight baselines around the Arctic Archipelago effective January 1,1986 is the most relevant and forceful, yet the most complex, claim to complete sovereignty in the Arctic. The U.S.S.R. has drawn similar baselines, although to a more limited extent, around the waters of its Arctic archipelagos since 1985. Several alternate grounds must be examined on which the drawing of straight baselines could possibly be based in international law, including customary international law as outlined in the Anglo-Norwegian Fisheries Case, the provisions of the 1958 Territorial Sea Convention and the provisions of the 1982 Law of the Sea Convention.

\section{(a) Customary International Law -- the Anglo-Norwegian Fisheries Case ${ }^{66}$}

In its 1951 decision in the Anglo-Norwegian Fisheries Case, the International Court of Justice held that under specified conditions international law permitted a coastal state to draw straight baselines from which its territorial sea could be measured. ${ }^{67}$ Thus, all waters within these baselines would be considered internal waters over which complete sovereignty could be exercised. The Court's decision applies to two geographic circumstances: "Where a coast is deeply indented and cut into, as is that of Eastern Finmark, or where it is bordered by an Archipelago such as the 'skjaergaard'..68 The Court also spelled out three flexible criteria to determine whether straight baselines should be permitted given the circumstances in question: ${ }^{69}$

(1) the general direction of the coast

(2) the close link between the land and the sea; and

(3) certain economic interests evidenced by long usage.

Given these criteria, the positions of Canada and the U.S.S.R. must be examined.

With respect to the geographic nature of Canada's Archipelago, most writers unquestioningly accept that it would fall within the parameters of the Fisheries case. ${ }^{70}$ It could be argued, however, that Canada is not "bordered by an archipelago such as the 'skjaergaard '", but rather is bordered by an archipelago of a very different nature. The two sides of this argument can be appreciated by questioning whether the Court was simply stating that the coastline must be rugged and indented and thus requires special adaptation (in which case Canada's Archipelago would satisfy the requirement), or whether the Court was really looking for a "fringe" of islands, as the International Law Commission described the Norwegian coast and which was eventually adopted in the 1958 Territorial Sea Convention (which Canada would have a much more difficult

66. [1951] I.C.J. Rep. 116.

67. McKinnon, supra, note 29 at 801.

68. Supra, note 66 at 128.

69. Canada's Arctic Waters in International Law, supra, note 13 at 135-136.

7o. For example, Pharand and McKinnon. 
time satisfying). ${ }^{71}$ The issue ultimately resolves itself into the question of which of these approaches now represents customary international law -- and thus more specifically, whether the provisions of the 1958 and 1982 Conventions reflect the customary international law for drawing straight baselines. It is submitted: (1) in its 1951 decision, the Court was most concerned with unique geographical circumstances to which existing legal principles regarding the determination of the territorial sea did not apply, and of which the Norwegian "skjaergaard" is just one example, (2) that neither the provisions of the 1958 nor the 1982 Conventions dealing with straight baselines reflect customary international law given that (a) only forty-six states have ratified the 1958 Territorial Sea Convention, (b) only twenty-six states had ratified the 1982 Law of the Sea Convention as at April 30, 1986 and (c) sixty states have drawn straight baselines around their archipelagos, at least eighteen of which are very doubtful "fringes" of islands if these provisions are narrowly interpreted ${ }^{72}$ and (3) because of this, Canada's Arctic Archipelago falls within the customary international law geographic requirements for drawing straight baselines. It must be conceded, however, that strong legal arguments exist on both sides of this debate, and arbitration could easily result in a decision going either way.

After fulfilling this threshold geographic requirement, one must also consider whether Canada satisfies the three specific criteria outlined by the Court in its decision (which have subsequently been incorporated into both the 1958 and 1982

Conventions). With respect to the general direction of the coast, it has generally been accepted that this criterion should be applied liberally and should be done with reference to a global large-scale map of the region, not requiring attention to specific details of the coast. ${ }^{73}$ Using a common sense and liberal approach, Canada's Archipelago can be seen to fit within these criteria; however, on a narrow interpretation, it could be argued that the western edge of the Archipelago runs virtually perpendicular to the general northern coastline of Canada. Using the functional approach of the Court, it is submitted that Canada would fulfil this requirement; however, it must again be admitted that a strong argument exists against Canada's claim. A similar debate exists with respect to the second of the Court's criteria, the necessity of a close link between the land and the sea. Although on the basis of a land to sea ratio, Canada would obviously satisfy this criterion (1:0.822 for Canada versus 1:3.5 for the Norwegian archipelago), ${ }^{74}$ greater problems may arise when looking at the physical distances between land masses in the archipelago. The Parry Channel, which clearly divides the Arctic Archipelago into two groups, is a potential impediment to finding a close land-sea connection for the entire area. However, given that the Archipelago forms a logical whole when viewed on a large-scale chart, that numerous rocks, reefs and islands fill most of the bodies of water within the Archipelago, the presence of ice for most of the year, the apparent geographical and geological unity of the region, the small sea to land ratio previously

McKinnon, supra, note 29 at 806.
Canada's Sovereignty over the Newly Enclosed Arctic Waters, supra, note 23 at 329-330.

73. McKinnon, supra, note 29 at 806.
Canada's Sovereignty over the Newly Enclosed Arctic Waters, supra, note 23 at 329-330.

See McKinnon, supra, note 29 at 804-805.

See Killas, supra, note 28 at 106 and Canada's Arctic Waters in International Law, supra, note 13 at $148-149$ and 161 . 
discussed and the liberal interpretation suggested by the Court, it is submitted that the region would fill the requirements of the Fisheries case in this regard. ${ }^{75}$ Finally, the International Court looked to economic use of the region to support the use of straight baselines. On Canada's behalf, it has been suggested that the economic interests of the Inuit who use the region for fishing and hunting could possibly satisfy this requirement. ${ }^{76}$ Closely related to this economic requirement is the doctrine of consolidation of title -- where "history is invoked only as a complementary and subsidiary basis, to solidify or consolidate the title resulting from the primary or main basis" (for example, in the case of drawing straight baselines). ${ }^{n}$ The requirements for historical consolidation are basically a weaker version of the historical title requirements previously discussed. Although historical title would most likely not be a basis for Canadian sovereignty on its own, Pharand submits that Canadian history under the guise of historical consolidation would provide significant support for the use of baselines in general and for the validity of several specific baselines in particular. ${ }^{78}$ Again, this aspect of the Court's criteria is subject to debate; however, given the Court's flexible attitude and an undeniable Canadian historical presence (even though not sufficient to be the sole basis for sovereignty) Canada would likely succeed in this regard.

\section{(b) The 1958 Territorial Sea Convention}

With respect to straight baselines, the 1958 Convention basically codified the 1951 Fisheries decision, however, with several major changes. The most important change is found in Article 4 of the Convention, where the geographical requirement for application to an archipelago is stated as "... if there is a fringe of islands along the coast in its immediate vicinity, the method of straight baselines ... may be employed ..." This provision has been interpreted as being much more restrictive than the customary international law outlined in the Fisheries case. ${ }^{79}$ The arguments in this regard have been outlined previously, and valid arguments exist for defining the entire Arctic Archipelago as a "fringe" (on a very liberal definition), for only including the southern islands of the Archipelago or for excluding the majority of the Archipelago (a very restrictive definition). It is clear, though, that relying on the provisions of the 1958 Convention would be a much riskier position for Canada than relying on the traditional customary international law. It should be noted that Canada has not ratified the 1958 Convention (although it has signed it) ${ }^{80}$ and is thus not bound by these more restrictive provisions unless they reflect the state of customary international law, which it has been submitted they do not.

The 1958 Convention also provides for a somewhat different result if baselines can be validly drawn. Under customary international law, waters inside baselines are

75. See Killas, supra, note 28 at 114.

76. Canada's Sovereignty over the Newly Enclosed Arctic Waters, supra, note 23 at 331.

n. Canada's Arctic Waters in International Law, supra, note 13 at 139-140.

78. Ibid. at 178.

79. McKinnon, supra, note 29 at 805.

80. Killas, supra, note 28 at 106. 
internal waters subject to complete national sovereignty. Under the 1958 regime, however, Article 5 provides that

Where the establishment of a straight baseline in accordance with Article 4 has the effect of enclosing as internal waters areas which previously had been considered as part of the territorial sea or of the high seas, a right of innocent passage ... shall exist in those waters.

The result under the 1958 Convention is thus not complete sovereignty, but is rather sovereignty tempered with a right to innocent passage -- a much weaker result from Canada's perspective, which would again favour use of customary international law.

The remainder of the provisions in the 1958 Convention with respect to straight baselines are a verbatim incorporation of the three criteria used by the International Court of Justice in the Fisheries case, and the legal arguments are thus identical. The only difference may be that the provisions of the Convention would be more strictly interpreted against Canada in favour of a "freedom of the seas" approach, which tended to underlie both the 1958 and 1982 Conventions. Overall, Canada can advance a claim to internal waters under the 1958 Convention, although its position would be significantly weaker than under customary international law.

\section{(c) The 1982 Convention on the Law of the Sea}

The 1982 Convention maintains the provisions of the 1958 Convention with respect to coastal archipelagos and straight baselines for fringes of islands in Article 7 (1), (3) and (5). ${ }^{81}$ The relevant arguments and conclusions in this regard are thus identical to section (b) above. Again, because of more restricted application and weaker results (the right of innocent passage in Article 8), customary international law provides a stronger basis for Canadian sovereignty claims.

The 1982 Convention, though, goes well beyond the 1958 Convention and makes explicit provision for mid-oceanic archipelagos. At least one author has suggested that Canada can make a claim by analogy to the provisions for mid-oceanic archipelagos should a coastal archipelago claim fail. ${ }^{82}$ The provisions concerned are found in Article 47 and permit the drawing of "straight archipelagic baselines" with specific water to land ratios and maximum baseline lengths (which the Canadian archipelago satisfies). The waters within these baselines would be considered "archipelagic waters", and would be subject to similar rights as waters enclosed under Article 7, but always subject to the right of innocent passage. ${ }^{83}$ It is submitted that this use of straight baselines is the weakest of those discussed, both in terms of possible legal arguments for the drawing of such baselines and in terms of the results achieved.

\section{B. THE STATUS OF THE NORTHWEST PASSAGE}


Regardless of whether the waters of the Arctic Archipelago are found to be internal, internal with a right of innocent passage or merely territorial and high seas, these sovereign and jurisdictional claims can be overridden if the Northwest Passage is found to be an international strait. Although the 1958 and 1982 Conventions specify the categories of straits and types of passage which will apply to them, customary international law must be relied on to define when a body of water is an international strait. The state of customary international law in this regard is best indicated by the Corfu Channel Case. ${ }^{84}$ In this case, the International Court of Justice concluded that "the decisive criterion is rather its geographical situation as connecting two parts of the high seas and the fact of its being used for international navigation. ${ }^{185}$ The 1958 and 1982 Conventions have considerably broadened the geographic criteria for straits to include passages connecting high seas with territorial seas or connecting two exclusive economic zones. ${ }^{86}$ The Northwest Passage clearly falls within the geographic criterion as it connects two parts of the high seas.

The functional or usage criterion mentioned by the Court, on the other hand, is much more unclear. Disputes have arisen as to whether use must be actual versus potential, how many transits of a passage are required before it is "used for international navigation" and so forth. The Corfu Channel case merely states that this usage is to be evidenced primarily by "the number of ships using the strait and the number of flags represented." ${ }^{87}$ As of 1985, 45 complete transits of the Northwest Passage had been made -- 29 by Canadian ships, eleven by American ships and five by ships from Norway, the Netherlands, Japan, Bahamia and Liberia. ${ }^{88}$ Aside from the first discovery passage, all voyages have been made with permission (whether this is a relevant consideration as to whether a passage is an international strait is unclear). It is submitted that of the sixteen foreign passages (slightly higher now, although the legal position is still the same) very few were made specifically due to the Passage being useful for international navigation. Purposes for voyages included exploration (one surface, two submarine), hydrographic surveys (three), support for the S/T Manhattan trial (four) and adventure (four). This leaves two U.S. icebreaker voyages (and potentially the Manhattan trial as well) as legitimate transits of the Northwest Passage due to its nature as a useful strait for international navigation. It is therefore submitted that the Northwest Passage is not an international strait based on the principles of customary international law.

If, however, the opposite view is accepted and the Northwest Passage is declared an international strait, the right of transit passage (as per the 1982 LOS Convention) or the right of non-suspendable innocent passage (as per the 1958 Convention and pre-existing customary law) will apply. ${ }^{89}$ The right of transit passage differs little from passage on the high seas, and includes rights of overflight. It should be noted

[1949] I.C.J. Rep. 4.

Ibid. at 28.

Canada's Arctic Waters in International Law; supra, note 13 at 221.

Ibid. at 224.

Canada's Sovereignty over the Newly Enclosed Arctic Waters, supra, note 23 at 338-341.

Canada's Arctic Waters in International Law, supra, note 13 at 233. 
that the declaration of the Northwest Passage as an international strait and the corresponding right of transit passage will only apply to internal waters created by the establishment of straight baselines. ${ }^{90}$ If the waters are historic waters, "no right of passage applies and the strait would normally not be capable of becoming an international strait." ${ }^{.91}$ However, even if the Northwest Passage is not currently an international strait or the waters are internal by virtue of historic title, the Passage can still become an international strait through international use without appropriate control measures. ${ }^{22}$ If this were to occur, the right of transit passage (or perhaps non-suspendable innocent passage, depending on the status of the 1982 LOS Convention) would again be applicable. To avoid this, Canada would have to take numerous legislative and functional steps to ensure control and enforcement of its policies in the Arctic. Thus, even though it is submitted that the Northwest Passage is not currently an international strait, the potential for it to become such is still very real.

\section{THE TERRITORIAL SEA \& EXCLUSIVE ECONOMIC ZONES}

The international rules regarding territorial seas and exclusive economic zones could be of relevance in Canada's Arctic in one of two ways. If the waters of the Archipelago itself are validly internal due to either the historic waters or straight baselines doctrines, a territorial sea of twelve nautical miles (Article 3 of the 1982 Convention) and an exclusive economic zone of 200 nautical miles (Article 57 of the 1982 Convention) will exist emanating from the outer edge of the baselines around the Archipelago. In the territorial sea, Canada would have complete sovereignty, subject to the right of innocent passage (Article 17); whereas in the exclusive economic zone Canada would have the right to explore, exploit, conserve and manage natural resources (Article 56) whereas other states would basically enjoy freedom of the seas (Article 58). Canada has not yet declared an exclusive economic zone, but since 1977 has had a 200-mile Arctic fishing zone based on the exclusive economic zone concept. ${ }^{93}$ On the other hand, if the waters of the Archipelago cannot validly be classified as internal waters (or perhaps archipelagic waters), the territorial sea and exclusive economic zone provisions will apply to each individual island in the Archipelago. Under this scenario, the entire Arctic Archipelago would undoubtedly fall within a Canadian exclusive economic zone, although this zone would not be quite as large as under a baseline system. Twelve mile territorial seas around the individual islands, though, would not be able to completely cover all of the waters lying within the Archipelago. The result would be that the waters of the Archipelago would be a mixture of territorial seas and high seas (wherever the twelve mile territorial seas of individual islands did not meet or intersect). Of most relevance under this regime is the fact that the Northwest Passage would be impossible to pass through without going through Canada's territorial seas. While much of the Passage would contain a high seas corridor, territorial seas would overlap in the Barrow Strait as well as the Prince

Ibid. at 223.

lbid.

Ibid. at 230.

Canada's Arctic Jurisdiction in International Law, supra, note 18 at 326. 
of Wales Strait, subjecting them to Canadian sovereignty. ${ }^{94}$ The effect of this regime would be to have complete freedom of the seas in the high seas corridor (subject now to the Arctic Waters Pollution Prevention Act, discussed below) and a right of innocent passage in the sections containing territorial seas. Of course, it is also possible under this scenario for the Northwest Passage to be declared an international strait overriding any territorial sea limitations, subject to the customary and treaty law discussed previously.

\section{JURISDICTION UNDER THE ARCTIC WATERS POLLUTION PREVENTION ACT}

In addition to the direct sovereignty claims discussed above, Canada has also enacted special legislation to assert jurisdiction over Arctic waters apart from any claim to title. In 1970, the Arctic Waters Pollution Prevention Act (AWPPA) was passed, asserting "Canada's right to shield the Arctic waters north of the 60th parallel against vessel pollution for a distance of 100 miles offshore. ${ }^{195}$ In implementing the Act, Canada established navigational standards within a series of shipping safety control zones in 1972. When first passed, it was generally thought the AWPPA violated existing principles of international law and, as could be expected, the United States raised a serious objection to Canada's jurisdictional claim. ${ }^{96}$ Through intense efforts on the part of the Canadian government, Article 234 was included in the 1982 Law of the Sea Convention to justify Canada's action. Although some still challenge the international legal effect of both Article 234 and the AWPPA, "[t]his provision has now rallied a sufficiently wide consensus in the international community that it may be considered as part of customary international law.."97 Under this view, regardless of whether states such as the U.S. adopt the 1982 Convention, Canada will have the ability to protect its northem marine environment. This jurisdiction would apply to all the waters of the Arctic Archipelago and 100 miles beyond regardless of the status of these waters or the Northwest Passage. It must be acknowledged, however, that significant arguments can be advanced against such a broad view of Article 234. A narrow interpretation would imply that the legislative and enforcement authority of Canada could be limited to severe climactic conditions, exceptional hazards to navigation and so forth, and where these conditions did not occur normal maritime rules would apply. ${ }^{98}$ As well, regardless of which interpretation was used, military vessels would not be bound by the AWPPA due to the principle of sovereign immunity. ${ }^{99}$ Article 234 and the AWPPA thus provide Canada with an additional means to exert jurisdiction over the waters of the Arctic, although the full extent of this jurisdiction is subject to dispute.

Canada's Sovereignty over the Newly Enclosed Arctic Waters, supra, note 23 at 335.

K.M. Shusterich, "International Jurisdictional Issues in the Arctic Ocean," (1984) 14:3 Ocean Development and International Law 235 at 250.

Canada's Arctic Jurisdiction in Intemational Law, supra, note 18 at 325.

Ibid.

D.M. McRae and D.J. Goundrey, "Environmental Jurisdiction in Arctic Waters: The Extent of Article 234" (1982) 16 U.B.C.L. Rev. 197 at 227.

Canada's Arctic Jurisdiction in International Law, supra, note 18 at 337. 


\section{E. THE NATURE OF SEA ICE -- CLAIMS TO ICE AS LAND}

Three aspects of sea ice must be considered with respect to claims of sovereignty and jurisdiction in the Arctic: (1) sea ice as a form of land (2) shelf-ice as a basis for determining straight baselines and (3) ice islands. The first of these claims can be dismissed rather summarily, as for the most part it has clearly been abandoned. The most extreme view of Arctic sea ice is that it is functionally similar to land and thus should be subject to absolute sovereignty as land. Various statements implicitly using this view to bolster other arguments have been made by Canadian and Soviet officials, although to a very limited extent. ${ }^{100}$ Any claims of this nature have been abandoned and Arctic sea ice has now been classified as water, although it is recognized as having a special status.

Shelf-ice, on the other hand, has been used by Canada for drawing the baselines around its Arctic Archipelago. ${ }^{101}$ Little has been said about this use of sea ice, although $^{102}$

the literature of international law shows general acceptance of the view that ice formations contiguous with the land domain and ice-shelves consisting of sea ice as well as glacier ice can be used for the determination of maritime zones - as long as the ice is comparatively permanent and stable.

The main argument against this view is the potential problem of measuring the territorial sea from a basepoint that is variable over time. In agreement with Killas, though, "[i]t is submitted that the use of ice-shelves for basepoints is a solution -consistent with international law - to a problem posed by environmental conditions." 103

Finally, the question has arisen as to the nature of ice islands located in the Arctic Ocean. These ice islands have been inhabited by scientific teams from the various Arctic states for long periods of time and have been the subject of jurisdictional questions in both domestic and international law. ${ }^{104}$ The general consensus of opinion would seem to indicate that "the coastal state can have no more jurisdiction over the activities of such an ice island than it would have if it were a ship." ${ }^{\text {"105 }}$ When ice islands enter Canada's exclusive fishing zone and 100-mile pollution prevention zone, they would thus be subject to Canadian jurisdiction under the relevant legislative regimes. For the most part, though, this question has not been addressed in international law.

\section{F. AVOIDING STATUS -- LACK OF SOVEREIGNTY IN THE ARCTIC}

S.B. Boyd, "The Legal Status of the Arctic Sea Ice: A Comparative Study and a Proposal, "in The Canadian Yearbook of International Law 1984 (Vancouver: UBC Press, 1985) 98 at 118-119.

Killas, supra, note 28 at 128.

Ibid. at 129.

Ibid. at 130.

Canada's Arctic Jurisdiction in International Law, supra, note 18 at 326-327.

Ibid. at 328. 
The final legal developments which must be considered are attempts and mechanisms to avoid clear sovereignty and jurisdictional claims over Arctic waters. These approaches include: The U.S. preference for high seas, the 1988 Canada-U.S. agreement on Arctic waters, Arctic cooperation in general and Inuit claims. Each of these views will be dealt with very summarily as the intent of this paper is to examine the adequacy of the legal regime of the Arctic, not to propose alternatives to that regime. As has become evident from many of the legal arguments discussed, the United States exhibits a clear preference for freedom of the seas and thus desires to keep as large a portion of the Arctic waters classified as high seas as possible. Any claims to sovereignty or jurisdiction can thus be expected to meet resistance from the U.S.

Apart from this American view, the other three issues listed above deal with potential solutions to Arctic needs outside of the realm of sovereignty versus free access claims. One of the most interesting developments to date is the Canada-United States Arctic Cooperation Agreement whereby the U.S. government has agreed to seek the consent of Canada before navigating the waters Canada claims as internal and both governments have agreed to cooperate in the area of Arctic waters research. ${ }^{106}$ It is submitted that when considering the legal regime of the Arctic with stark, functional reality, this single agreement is the law of transit of Arctic waters. This agreement explicitly ignores Canada's sovereignty claims and the opposition of the United States, yet it has successfully governed all foreign voyages through the Northwest Passage since 1988. A number of other bilateral and multilateral agreements and arrangements exist to deal with issues relating to the Arctic waters. These include: The International Convention on the Regulation of Whaling, ${ }^{107}$ the Agreement on the Conservation of Polar Bears, ${ }^{108}$ a Joint Marine Pollution Contingency Plan for the Beaufort Sea between Canada and the U.S. ${ }^{109}$ a memorandum of understanding regarding pollution control research between the U.S. Coast Guard and the Canadian Department of the Environment, the Marine Environment Cooperation Agreement between Canada and Denmark, ${ }^{110}$ as well as numerous others. ${ }^{111}$ Again, for the most part, these agreements do not mention or rely on any rigid concept of sovereignty based on historical title or the drawing of baselines, yet they provide effective functional solutions to needs in the Arctic. Finally, an emerging force in the Arctic is the Inuit Circumpolar Conference, a non-governmental organization working towards the development of a comprehensive Arctic policy based on protection of the Arctic environment. The efforts of this group are already having a major impact on Arctic literature, and it is believed they will eventually be a significant guiding force in international negotiations and policies. ${ }^{12}$ Interestingly, the Inuit have the greatest

Icebreaker Voyages in Arctic - U.S. - Canadian Agreement, supra, note 49 at 340. 10 November 1948, 161 U.N.T.S. 72, 4 Bevans 248.

26 May 1976, 27 U.S.T. 3918, 13 I.L.M. 13.

Canada-United States Marine Pollution Contingency Plan for Spills of Oil and Other Noxious Substances, Annex IV Concerning the Beaufort Sea 29 U.S.T. 2569, the text of the Treaty is also attached as an appendix to the Migratory Birds Convention Act, R.S.C. 1970, c. M-12.

For the text of this agreement see 23 I.L.M. 269.

VanderZwaag, Donihee \& Faegteborg, supra, note 3 at 15-17.

Ibid. at 26-27. 
stake in the Arctic and have been used to support a variety of nationalistic claims to sovereignty, yet their efforts at developing an international legal regime consistent with the needs of the Arctic must be carried on without any official standing or sovereignty in international law whatsoever. Overall, it is rather enlightening to contrast the effectiveness of these functional approaches to Arctic needs with the frequently academic battles regarding formal sovereignty over Arctic waters.

\section{THE LEGAL FRAMEWORK OF ARCTIC WATERS - A SYNTHESIS}

The complex effects of the overall legal framework discussed above are synthesized and summarized in the following table:

Table 2

THE LEGAL REGIME OF THE ARCTIC

\begin{tabular}{|c|c|c|c|c|}
\hline Theory & Hypothesis & Probability & Result & Subject To \\
\hline sector theory & $\begin{array}{l}\text { not valid in int'l } \\
\text { law }\end{array}$ & $100 \%$ & no effect & N/A \\
\hline historic waters & $\begin{array}{l}\text { Canadian waters } \\
\text { nol historic }\end{array}$ & $80-90 \%$ & $\begin{array}{l}12 \text { mile } \\
\text { territorial sea } \\
\text { a round each } \\
\text { island/some } \\
\text { high seas }\end{array}$ & $\begin{array}{l}\text { AWPPA } \\
\text { NW Passage }\end{array}$ \\
\hline & $\begin{array}{l}\text { Caradian waters } \\
\text { historically }\end{array}$ & $10-20 \%$ & $\begin{array}{l}\text { complete } \\
\text { internal waters; } \\
\text { no innocent } \\
\text { passage }\end{array}$ & NW Passage \\
\hline straight baselines & $\begin{array}{l}\text { valid lines in } \\
\text { customary int'l } \\
\text { law (Fisheries) }\end{array}$ & $60-80 \%$ & $\begin{array}{l}\text { complete } \\
\text { internal waters; } \\
\text { no innocent } \\
\text { passage }\end{array}$ & NW Passage \\
\hline & $\begin{array}{l}\text { valid lines by } \\
\text { treaty law (1958 } \\
\& 1982 \text { LOS } \\
\text { Conv.) }\end{array}$ & $40.60 \%$ & $\begin{array}{l}\text { internal waters } \\
\text { with right of } \\
\text { innocent passage }\end{array}$ & $\begin{array}{l}\text { NW Passage } \\
\text { AWPPA }\end{array}$ \\
\hline & $\begin{array}{l}\text { Canadian lines } \\
\text { invalid }\end{array}$ & $20-60 \%$ & $\begin{array}{l}12 \text { mile } \\
\text { territorial sea } \\
\text { around each } \\
\text { island/some } \\
\text { high seas }\end{array}$ & $\begin{array}{l}\text { AWPPA } \\
\text { NW Passage }\end{array}$ \\
\hline
\end{tabular}




\begin{tabular}{|c|c|c|c|c|}
\hline \multirow[t]{2}{*}{$\begin{array}{l}\text { Northwest } \\
\text { Passage }\end{array}$} & $\begin{array}{l}\text { intemational } \\
\text { strait (treaty \& } \\
\text { customary law) }\end{array}$ & $10-20 \%$ & $\begin{array}{l}\text { right of transit } \\
\text { passage in strait } \\
\text { overides other } \\
\text { principles }\end{array}$ & AWPPA \\
\hline & not an int'l strait & $80-90 \%$ & $\begin{array}{l}\text { none - other } \\
\text { principles } \\
\text { remain } \\
\text { unchanged }\end{array}$ & $\begin{array}{l}\text { future use \& } \\
\text { controls }\end{array}$ \\
\hline \multirow[t]{3}{*}{ AWPPA } & $\begin{array}{l}\text { valid under } \\
\text { customary int'l } \\
\text { law }\end{array}$ & $60-80 \%$ & $\begin{array}{l}100 \text { mile } \\
\text { pollution control } \\
\text { ju ris diction } \\
\text { overrides other } \\
\text { principles }\end{array}$ & N/A \\
\hline & $\begin{array}{l}\text { valid under } \\
\text { treary (1982 } \\
\text { Conv. s. 234) }\end{array}$ & $80-90 \%$ & $\begin{array}{l}100 \text { mile } \\
\text { pollution control } \\
\text { jurisdiction } \\
\text { overrides other } \\
\text { principles }\end{array}$ & $\begin{array}{l}\text { only binds } \\
\text { signatories } \\
\text { - Canada? } \\
\text { - U.S.??? }\end{array}$ \\
\hline & $\begin{array}{l}\text { not customary } \\
\text { law not valid } \\
\text { under treaty law } \\
\text { or for non. } \\
\text { signatories }\end{array}$ & $10-40 \%$ & $\begin{array}{l}\text { none - other } \\
\text { principles } \\
\text { remain } \\
\text { unchanged }\end{array}$ & $\begin{array}{l}\text { customary law } \\
\text { developments \& } \\
\text { more treaty } \\
\text { signatures }\end{array}$ \\
\hline \multirow[t]{3}{*}{ sea ice } & $\begin{array}{l}\text { claim } \\
\text { sovereignty as } \\
\text { land }\end{array}$ & $0 \%$ & no effect & N/A \\
\hline & $\begin{array}{l}\text { use shelf-ice for } \\
\text { basepoints }\end{array}$ & $?$ & $\begin{array}{l}\text { minor effect on } \\
\text { precise way } \\
\text { baselines are } \\
\text { drawn }\end{array}$ & $N / A$ \\
\hline & $\begin{array}{l}\text { ice islands } \\
\text { treated as vessels }\end{array}$ & $?$ & $\begin{array}{l}\text { no effect on } \\
\text { overall } \\
\text { sovereignty }\end{array}$ & N/A \\
\hline
\end{tabular}

\footnotetext{
*Note: for all of the above, bilateral and multilateral agreements and arrangements may apply and would functionally override the theoretical legal principle outlined
}

From the synthesis outlined in the table, the continuing uncertainty of the legal framework applicable to the Arctic can be appreciated. For example, even if the straight baselines Canada has drawn around its Arctic Archipelago are valid, uncertainty remains as to whether the "internal waters" are subject to a right of innocent passage and whether the Northwest Passage is an international strait subject to rights of transit passage. And, even if not currently an international strait, the Northwest Passage is subject to potential change in terms of both how the Passage is classified under existing law (that is, if it is used more and not controlled properly, it could be reclassified) and potential changes to the law pertaining to international straits in general. In fact, it should be stressed that the principles of international law are never static, but continuously develop due to state practices, new agreements and so forth. Therefore, given that the law of the sea is still in an embryonic phase and that state practice in this area is still highly divergent, claims to sovereignty based on current international legal principles cannot guarantee that the rules will not have changed in ten or twenty years.

Examining the legal regime of the Arctic waters as a whole, one is thus drawn to the ultimate conclusion that the ability of any state to claim complete sovereignty in the 
Arctic based on existing principles of international law is very doubtful. The potential legal outcomes for an Arctic waters regime vary on a continuum from mere territorial waters, high seas and a right of transit passage through the Northwest Passage on one extreme, to absolute internal waters with no rights of passage and blanket pollution prevention coverage under the AWPPA on the other extreme. Where exactly a judicial interpretation would fall is anyone's guess. Based on the mid-points of the subjective probabilities listed in Table 2, the probability of Canada achieving complete sovereignty over its waters is approximately $65 \%$. On the other hand, the probability of Canada being left with no jurisdiction beyond control of its territorial seas is under $10 \%$. Between these extremes lie a variety of more probable "compromises" where Canada would obtain partial sovereignty or limited jurisdiction subject to a variety of potential rights of other states.

The sovereign rights claimed by Canada become even more untenable when the realities of international law in general are taken into account. Even if Canada attains complete sovereignty over the waters of its Arctic Archipelago, there are numerous factors over which Canada will have no control. Although an environmental disaster may never occur in Canadian waters, ocean currents in the Arctic are such that Canada could be affected by pollution occurring anywhere in the region. Despite sovereign claims, Canada would still be subject to transboundary pollution from water, land and air based sources, not only from other Arctic states, but from all regions of the earth. With concepts such as state responsibility just beginning to take shape in international law, a system based on strict concepts of sovereignty and state rights may be an inappropriate forum in which to manage the needs of the Arctic. This is further emphasized by recognizing both the costs that would be associated with maintaining Arctic sovereignty and the lack of enforcement mechanisms in international law if breaches of Canada's sovereign rights did occur. To date, Canada has been unwilling and unable to take the steps necessary to assert functional jurisdiction over its Arctic waters ${ }^{113}$ and, in any event, it is highly questionable whether an antagonistic approach to the maintenance of state sovereignty would be a satisfactory basis for international relations in the Arctic. Finally, one only needs to remember that the functional solutions which exist in bilateral and multilateral agreements today have largely ignored or avoided claims to sovereignty over the Arctic waters to arrive at the ultimate conclusion that a sovereignty based regime likely has little to offer in terms of successfully managing the varied interests arising in the Arctic.

\section{CONCLUSION}

From their initial status as a barren and inhospitable wasteland, the waters of the Arctic have quickly become a vital strategic military arena for the world's superpowers, a valuable source of and conduit for natural resources and, ultimately, the subject of an intense political and legal debate regarding their use and control. To date, the focus of international legal efforts has revolved around the issue of sovereignty and jurisdiction over Arctic waters. It is quickly becoming clear, however, that these efforts, and a sovereignty based legal regime in general, will be unable to meet the complex and critical

113. The Canadian government's plans to monitor the Arctic waters with a class 8 icebreaker have apparently not yet been fulfilled, and plans to construct several nuclear submarines for Arctic surveillance have been put in abeyance due to financial constraints. 
management needs of this region. The legal principles applicable to the Arctic waters are extremely uncertain, and the entire law of the sea, especially with respect to Arctic regions, is still in a state of developmental change. Even if completely certain, formal legal rights would be expensive to administer, almost impossible to enforce and, overall, hopelessly inadequate to meet the diverse economic, political, social and environmental needs of the region. The management problems regarding Arctic waters are global in the truest sense, and as has been witnessed by the functional progress demonstrated by individual cooperative agreements, the solutions are also global. Individual state-centred sovereign and jurisdictional claims to this vital frontier clearly cannot succeed. Success to date has stemmed from international Arctic cooperation -- and the political environment has never been more conducive to extending this success to a broad range of communal Arctic interests. Hopefully, the states of the Arctic littoral will be able to harness the energy they have expended on working towards a divisive legal framework and instead apply it to an Arctic legal regime based on mutual recognition of Arctic interests and cooperative responses to the unique regional and global requirements of this final frontier. 